\title{
Ultrasound-induced settleability and membrane filterability of activated sludge treating milk processing wastewater
}

\author{
Z. Rahimi ${ }^{1} \cdot$ A. A. Zinatizadeh ${ }^{1}$
}

Received: 16 February 2018 / Accepted: 4 September 2018 / Published online: 25 September 2018

(c) The Author(s) 2018

\begin{abstract}
In practice, established operation of activated sludge treatment system with high biomass concentration is restricted because of difficulty in settling the sludge in clarifiers. Membrane bioreactor is a modified form of activated sludge, and despite the superior advantages, its widespread application is restricted by the membrane fouling. Therefore, in this research, to improve the sludge sedimentation at high biomass concentration in the activated sludge system, high-frequency ultrasound $(1.7 \mathrm{MHz})$ was exerted in clarifier of activated sludge system and its performance was compared with a bioreactor followed by an antifouling ultrafiltration membrane. The antifouling ability of $\mathrm{NH}_{2}$-functionalized multiwall carbon nanotubes $\left(\mathrm{NH}_{2}\right.$-MWCNTs)-modified nanocomposite UF membrane during filtration of mixed liquor-activated sludge was investigated. Hydraulic retention time (HRT) (8-44 h) and mixed liquor suspended solids (MLSS) (6000-14,000 mg/L) were chosen as the operating variables to analyze the process. The biological process showed high COD removal efficiency throughout the experiments (>96\%). The membrane and high-frequency ultrasound had no effect on the system performance in terms of COD, TKN, TN, TP removal. However, the HRT and MLSS indicated an increasing impact on flux. The effect of ultrasound on the sludge properties, i.e., sludge volume index, sludge settling velocity and height of sludge at high MLSS concentration $(14,000 \mathrm{mg} / \mathrm{L})$, was not considerable. It was concluded at MLSS of below 10,000 mg/L, about $40 \%$ water recovery was obtained. As a result, activated sludge equipped with ultrasound showed a promising performance; however, its industrial development needs further examinations to attain the design criteria.
\end{abstract}

\section{Graphical Abstract}

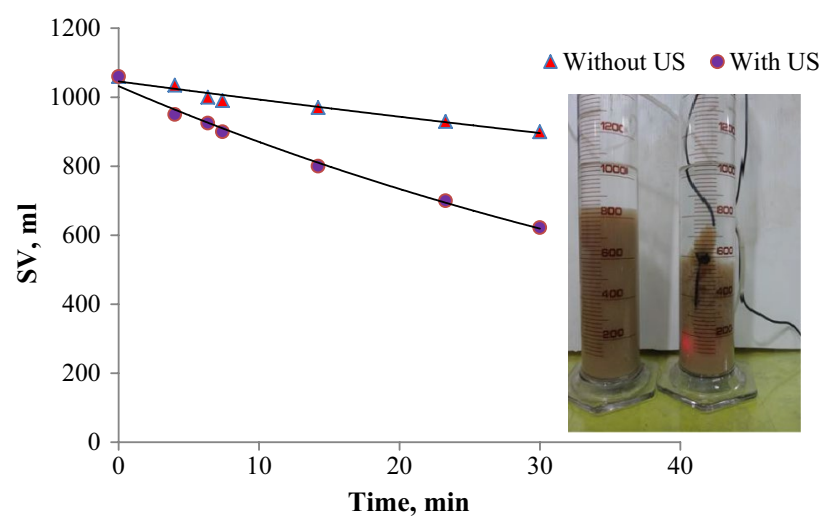

Keywords Conventional activated sludge $\cdot$ Antifouling UF membrane $\cdot$ High-frequency ultrasound $\cdot$ Milk processing wastewater

A. A. Zinatizadeh

zinatizadeh@ razi.ac.ir; zinatizadeh@gmail.com

Extended author information available on the last page of the article 


\section{Introduction}

Over recent years, various techniques such as physical, chemical and biological methods have been employed for wastewater treatment. However, among these methods, the biological treatment technology especially conventional activated sludge (CAS) systems is widely used for treating different types of wastewaters (Pell and Wörman 2011). Overall, in biological treatment systems reaching an optimal biodegradation capability are vital for more effective microcontaminants removal. As far as the degradation mechanism of some pollutants is unknown (Sipma et al. 2010), the biodegradation potential of such micropollutants is generally low specially in the CAS systems owing to low biomass concentrations and relatively low sludge age (Sipma et al. 2010). Generally, the more biomass concentrations provide more biodegradation capacity in the biological treatment systems. Nevertheless, imposing high biomass loading to these conventional systems is somewhat difficult due to poor sludge settling in this situation. Consequently, parts of the sludge end up in treated water which results in low quality of the treatment process (Matošić et al. 2009). So, some researchers have paid much attention to this issue and presented some methods to keep the microbial community at high level of concentration along with easy separation of sludge from treated effluent without enlarging footprint (Chan et al. 2009; Jianlong et al. 2000; Zinadini et al. 2015; Liang et al. 2010; Luostarinen et al. 2006; Andrade et al. 2014). Membrane bioreactors (MBRs) have recently attracted many attentions from this point of view. It has been documented in the literature an MBR, known as an amendment of the CAS process, employs membrane in place of clarifier to remove sludge from the treated water; thereby, suspended solids concentration within the bioreactor can be kept at a much higher level (Visvanathan et al. 2000; Rhoida Eco Services Group 1998). This technology presents several benefits in comparison with the CAS system (Cicek 2003; Matošić et al. 2009). Despite numerous advantages, the membrane fouling still remained as a serious barrier, and efforts are still under investigation to overcome this problem (Hai et al. 2005; Sombatsompop 2007). The membrane filtration is well recognized as a versatile technology and has been used in other popular biological treatment system called microbial fuel cell (MFC). The MFC as an efficient device is able to treat wastewater and also produce energy concurrently (Ghasemi et al. 2016a, b, 2017). However, the membrane technology is still perplexed by fouling problem and high capital cost. In this regard, also myriad studies have been conducted to lessen the relevant problems (Ghasemi et al. 2016a, b).

Ultrasound is defined by the high-frequency $(>16,000 \mathrm{~Hz})$ propagation of pressure waves in a fluid (Gibson et al. 2009). The ultrasound is categorized into: (1) high-frequency and low-power (1-10 MHz range) ultrasound and (2) low-frequency and high-power $(20-100 \mathrm{kHz})$ ultrasound, based on the frequency range (Mason 2007). At low frequencies, the bubble has more time to grow and therefore the cavitational collapse is more violent and larger, generating more powerful hydrodynamic shear forces (Bussemaker and Zhang 2014). Consequently, some researches are being done to improve mass transfer using the lower frequency range. Additionally, the special interests in the use of the low-frequency ultrasound are concentrated on disturbing particles and reducing their size (Gibson et al. 2009). By contrast, at the higher ultrasonic frequencies, cavitation bubbles are more difficult to form, and those produced are smaller and more stable (Mason and Lorimer 2002; Kanthale et al. 2008; Bussemaker and Zhang 2014). These thin bubbles cause the movement of fluid along transducer axis; then, produced acoustic waves hit the upper surface and return to the fluid. Thus, the microbial flocculation will be enhanced, and subsequently, the sludge settling time is decreased (Gondrexon et al. 1998). Therefore, considering effective role of ultrasonic waves in formation of the sludge flocs, Zinadini et al. (2015) have compared the process performance of two sequence batch reactors (SBR) with/without employing ultrasonic transducer. The obtained findings showed that the high-frequency ultrasound led to considerable enhancement in sludge settling velocity at high mixed liquor suspended solids (MLSS) of $5000 \mathrm{mg} / \mathrm{L}$. In addition, Rezaee et al. (2014) examined simultaneous removal of carbon, nitrogen and phosphorus (CNP) in an innovative up-flow anaerobic/aerobic/anoxic bioreactor (UAAASB) induced by ultrasound. Based on their report, ultrasonic irradiation showed effective impact on the sludge settling velocity and effluent turbidity.

In this research, in order to enhance the CAS capacity with a similar performance to an MBR system but without the challenges associated with membrane filtration, an ultrasound-equipped activated sludge (ASUS) system was proposed for treating milk processing wastewater (MPW). And the process performance of the proposed system was compared with once the US device was not used. Furthermore, in this study, fouling tendency of membrane was studied by applying $0.1 \mathrm{wt} \%$ $\mathrm{NH}_{2}$-functionalized multiwalled carbon nanotubes (MWC$\mathrm{NTs})\left(\mathrm{NH}_{2}\right.$-MWCNTs)-embedded polyethersulfone (PES) ultrafiltration membrane, synthesized in our earlier study. The modified membrane with $0.1 \mathrm{wt} \%$ of $\mathrm{NH}_{2}$-MWCNTs was selected as an optimum membrane due to its good antifouling property (Rahimi et al. 2015). Finally, in order to evaluate the process performance, the flux parameter in membrane unit under 3 bar pressure, sludge volume index (SVI), settling velocity and height of sludge in ultrasoundequipped system and also treatment efficiency as effluent 
turbidity, removal parameters such as COD, TN, TKN and TP for both systems were evaluated.

\section{Materials and methods}

\section{Composition of milk processing wastewater}

The influent feed was prepared based on our previous study as follows (Rahimi et al. 2016). At first, certain amount

Table 1 Milk processing wastewater characteristics

\begin{tabular}{llcl}
\hline Parameter & Unit & Range & Average \\
\hline TCOD & $\mathrm{mg} / \mathrm{L}$ & $1906.3-2513$ & 2131 \\
$\mathrm{BOD}_{5}$ & $\mathrm{mg} / \mathrm{L}$ & $1372-1809$ & 1535 \\
$\mathrm{TN}$ & $\mathrm{mg} / \mathrm{L}$ & $245-296$ & 273 \\
$\mathrm{TP}$ & $\mathrm{mg} / \mathrm{L}$ & $55.3-72.9$ & 60.20 \\
$\mathrm{TKN}$ & $\mathrm{mg} / \mathrm{L}$ & $218.4-240.8$ & 232.6 \\
$\mathrm{NO}_{3}{ }^{-}$ & $\mathrm{mg} / \mathrm{L}$ & $21.7-47.7$ & 38.11 \\
$\mathrm{Turbidity}^{-}$ & $\mathrm{NTU}$ & $110-353$ & 176.4 \\
$\mathrm{pH}$ & - & $5-6$ & 5.5 \\
\hline
\end{tabular}

of low-cream milk was mixed with potable water in order to reach $\mathrm{pH}$ of around 5-6 and chemical oxygen demand (COD) of $2000 \mathrm{mg} / \mathrm{L}$. The resultant wastewater showed very similar characteristics to effluents obtained from dairy industries. This milk processing wastewater (MPW) was kept in a refrigerator at $4{ }^{\circ} \mathrm{C}$ before use. The ratio of COD/N/P was set as 100:15:3 for influent feed. In order to assess the phosphorous removal capacity, $\mathrm{KH}_{2} \mathrm{PO}_{4}$ was added into influent feed as supplement. Wastewater used in this study was characterized and is presented in Table 1.

\section{Bioreactor setup and operation}

The schematic of laboratory-scale bioreactor employed in this work is depicted in Fig. 1. The CAS system comprised of an aeration tank and a settling tank with total volume of 14.74 and $6.45 \mathrm{~L}$, respectively, was designed and fabricated. The working volume of the aeration tank was determined $5.46 \mathrm{~L}$. The aeration tank was aerated via an air stone submerged at the bottom of the reactor. The applied air flow rate and concentration of dissolved oxygen (DO) into the bioreactor were $2.5-5 \mathrm{~L} / \mathrm{min}$ and $3-4 \mathrm{mg} / \mathrm{L}$, respectively. This amount of the air flow rate provided not only required

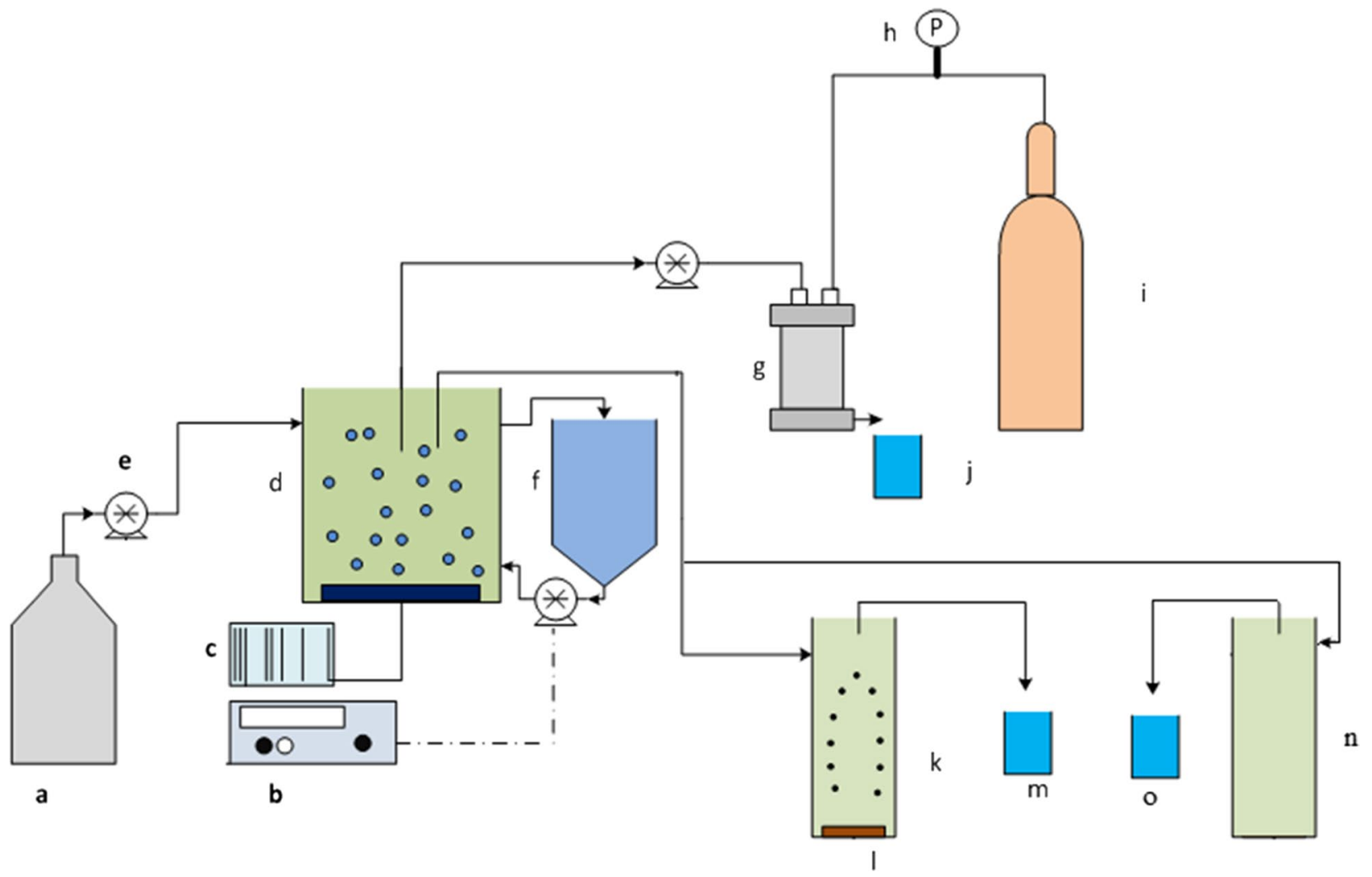

Fig. 1 Experimental setup used in this study. a Feed tank, b timer, c air pump, $\mathbf{d}$ bioreactor, e peristaltic pump, $\mathbf{f}$ settling tank, $\mathbf{g}$ filtra$\mathbf{k}$ container with US, $\mathbf{l}$ ultrasound transducer, $\mathbf{m}$ reactor effluent with US, $\mathbf{n}$ container without US, $\mathbf{o}$ reactor effluent without US tion cell, $\mathbf{h}$ pressure gauge, $\mathbf{i}$ nitrogen cylinder, $\mathbf{j}$ permeate reservoir, 
mixing into the bioreactor, but also supplied enough dissolved oxygen for aerobic biocatalysts. To provide the required biomass concentration into the biological system, a clarification was placed after the aeration tank. The sludge periodically was returned from settling chamber bottom to the aeration tank by means of the recycle activated sludge (RAS) pump (Sisdoz-PRS6) controlled by a timer. Feeding was done using peristaltic pump (PD5201, Heidolph, Germany) with adjustable speed and analogue tuner.

The reactor was continuously fed with a milk processing wastewater with the COD concentration about $2000 \mathrm{mg} / \mathrm{L}$. The reactor was inoculated with activated sludge taken from an industrial wastewater treatment plant (Bisotun, Kermanshah, Iran). The steady-state performance was assessed under different conditions of mixed liquor suspended solids (MLSS) concentrations of 6000-14,000 mg/L and hydraulic retention time (HRT) of 8-44 h at three levels. The experimental conditions are displayed in Table 2. Variation of $\pm 5 \%$ in the effluent COD concentration in each condition was considered as the criterion for steady-state conditions. $\mathrm{pH}$ adjustment was not necessary, as it was kept fairly constant (7-8) throughout the experiments. After being provided steady-state conditions, filtration performance of the selected membrane was assessed using mixed liquor from the aeration tank.

The selected ultrafiltration membrane was put on rigid sponge and placed in the dead-end stirred cell. The cell was fitted with a pressure gauge, and pressurized nitrogen gas was applied to force the liquid to pass through the membrane. The feed solution was stirred at the rate of $400 \mathrm{rpm}$ to prevent concentration polarization. At the beginning, the membrane was hydraulically compressed at 4 bar for $15 \mathrm{~min}$ with the pure water to inhibit the compaction effect of the membrane and finally reach steady-state conditions. Then, the pressure was decreased to the operating pressure of $3 \mathrm{bar}$. The permeates drawn from the membrane were measured by an electronic balance (BP2215, Sartorius, Germany) to

Table 2 Experimental conditions carried out

\begin{tabular}{lll}
\hline Run & \multicolumn{2}{l}{ Variables } \\
\cline { 2 - 3 } & Factor 1 & Factor 2 \\
& A: HRT & B: MLSS \\
& H & mg/L \\
\hline 1 & 8 & 6000 \\
2 & 8 & 10,000 \\
3 & 8 & 14,000 \\
4 & 26 & 6000 \\
5 & 26 & 10,000 \\
6 & 26 & 14,000 \\
7 & 44 & 6000 \\
8 & 44 & 10,000 \\
9 & 44 & 14,000 \\
\hline
\end{tabular}

determine the membrane flux and investigate antifouling properties. The filtered samples were gathered in a vessel to measure the next process parameters. The permeating flux was calculated from the quantity of permeate gathered through the membrane over a given time period via equation below.

$J=\frac{V}{A \Delta t}$

where $V(\mathrm{~kg})$ is the weight of the collected permeates, $A\left(\mathrm{~m}^{2}\right)$ is the membrane area, and $\Delta t(\mathrm{~h})$ is the permeation time.

The biological performance and also sludge compaction of the CAS were investigated with and without the presence of ultrasound transducer. In this mean, a sample of mixed liquor from the aeration basin was taken and moved into two bioreactors of $1.3 \mathrm{~L}$, in which one of them was equipped with a 1.7-MHz piezoelectric ultrasound transducer (Model ANN-2517GRL, Annon Piezo Technology Co. Ltd, China). Sludge settleability test with and without ultrasonic transducer was examined for $120 \mathrm{~min}$, and then, sludge settling velocity was measured; finally, the resultant supernatant was used to measure the process parameters.

\section{Analytical methods}

The parameters of $\mathrm{COD}, \mathrm{BOD}_{5}, \mathrm{TN}, \mathrm{TKN}, \mathrm{NO}_{3}{ }^{-}$, MLSS and SVI were analyzed based on standard methods (APHA 1999). For COD, a colorimetric method with closed reflux method was developed. Spectrophotometer (DR 5000, Hach, USA) at $600 \mathrm{~nm}$ was used to measure the absorbance of COD samples. The concentration of dissolved oxygen (DO) into bioreactor was measured by means of a DO probe supplied by WTW DO Cell OX 330, electro DO probe, Germany. A turbidity meter model $2100 \mathrm{P}$ (Hach Co., USA) was used to measure turbidity. Sludge volume index (SVI) was used to quantify the settling characteristics of the mixture of liquid-solid suspensions from both clarifiers, viz. with and without ultrasound transducer. Sludge settling velocity was measured according to a study of Zheng et al. (2005).

\section{Results and discussion}

\section{Biological treatment performance in bioreactor}

The bioreactor was operated with MLSS concentrations of $6000,10,000$ and $14,000 \mathrm{mg} / \mathrm{L}$ at three HRTs $(8,6$ and $44 \mathrm{~h})$. In this section, performance of the bioreactor in terms of carbon and nutrients removal is discussed. The effects of membrane filtration and ultrasound-equipped clarifier on the combined system performance will be presented in the sections below in separate. 
Table 3 The average removal efficiency of the main physicochemical parameters of the bioreactor effluent

\begin{tabular}{|c|c|c|c|c|c|c|c|c|}
\hline \multirow[t]{2}{*}{ Run no. } & \multicolumn{4}{|c|}{ Effluent (mg/L) } & \multicolumn{4}{|c|}{ Removal (\%) } \\
\hline & COD & TKN & $\mathrm{TN}$ & TP & COD & TKN & $\mathrm{TN}$ & TP \\
\hline 1 & 99 & 201.6 & 205.4 & 35.8 & 95.3 & 0.1 & 19.8 & 59.7 \\
\hline 2 & 85.7 & 134.4 & 139.6 & 21.2 & 96.0 & 0.38 & 40.0 & 55.7 \\
\hline 3 & 119.9 & 127.7 & 132.2 & 25.4 & 94.4 & 0.43 & 41.6 & 60.0 \\
\hline 4 & 144.4 & 121.0 & 135.5 & 23.8 & 93.2 & 0.41 & 58.6 & 59.4 \\
\hline 5 & 97.2 & 134.4 & 140.7 & 16.6 & 95.4 & 0.44 & 50.1 & 55.0 \\
\hline 6 & 69 & 131.0 & 129.6 & 22.7 & 96.8 & 0.45 & 59.1 & 57.3 \\
\hline 7 & 157.2 & 134.4 & 129.7 & 25.6 & 92.6 & 0.52 & 52.5 & 61.9 \\
\hline 8 & 42.2 & 134.4 & 139.2 & 11.9 & 98.0 & 0.43 & 48.0 & 55.7 \\
\hline 9 & 22.3 & 124.3 & 139.6 & 22.8 & 99.0 & 0.43 & 57.3 & 72.6 \\
\hline
\end{tabular}

Fig. 2 COD removal at different operating conditions

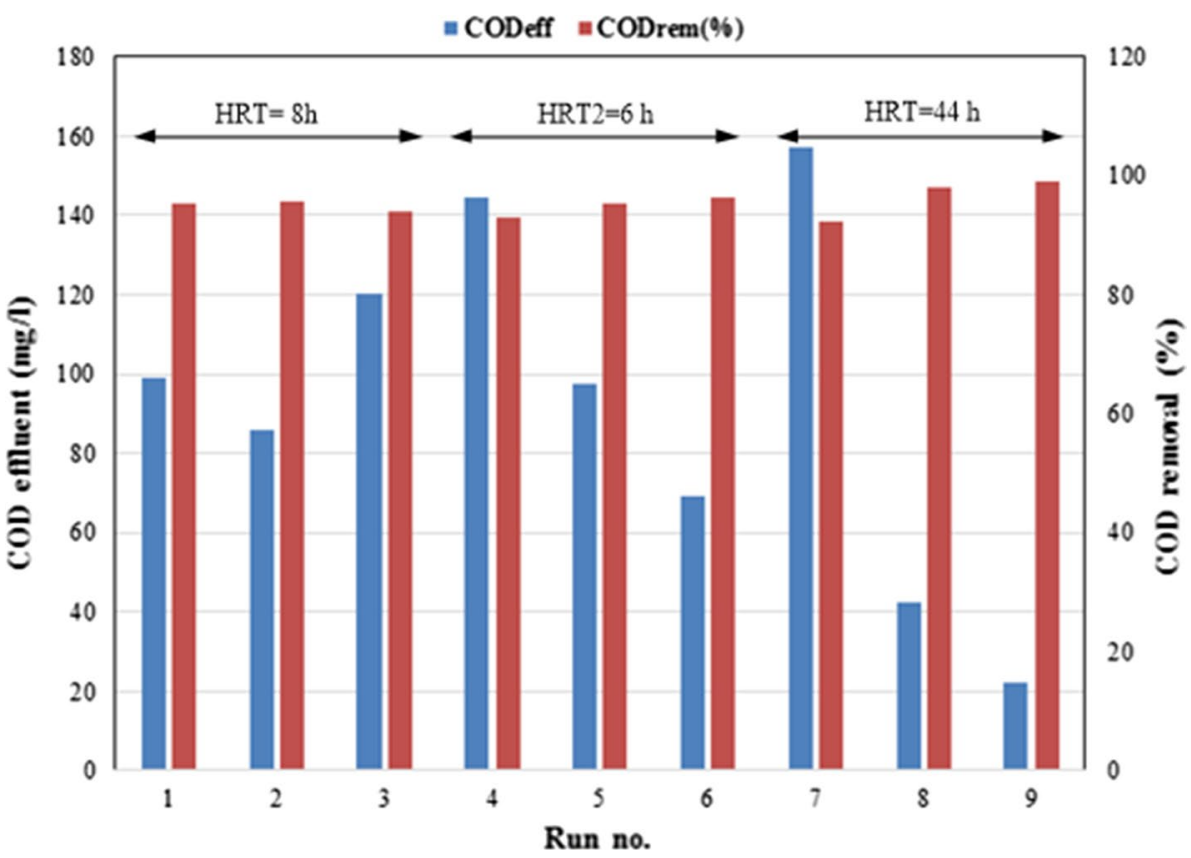

Table 3 indicates the average removal efficiency of the main physicochemical parameters of the bioreactor effluent throughout the experiments. Figure 2 shows effluent COD concentration and the respective removal efficiency in steady-state conditions. This figure has been plotted on the basis of the experiments number as shown in Table 2 . The $\mathrm{BOD}_{5}$ to COD ratio was obtained as 0.72 , and sludge retention time (SRT) was between 5 and 14 days. As clearly displayed in the figure, the bioreactor indicated a stable behavior in relation to COD removal throughout the design space, which means range of variables studied in this work, i.e., MLSS and HRT. The range of COD removal attained over various operational conditions was $>96 \%$. It might be attributed to high biodegradability of the wastewater and high biomass concentration employed in the bioreactor (Andrade et al. 2013). High COD removal efficiencies have been also reported for the treatment of whey wastewater generated upon cheese manufacturing (Farizoglu et al. 2004; Castillo et al. 2007).

In addition to the high COD removal, the system also showed to be efficient in removal of nutrients. High MLSS concentrations $(10,000$ and $140,000 \mathrm{mg} / \mathrm{L})$ usually lead to the occurrence of simultaneous nitrification and denitrification (SND) processes and nitrogen removal (Hocaoglu et al. 2011). In this system, TKN was removed through nitrification process and assimilation for cell growth. Low food to microorganism $(\mathrm{F} / \mathrm{M})$ ratio usually favors nitrification process (Andrade et al. 2013). In this study, the F/M ratio was in the range of 0.1-1.06 $\mathrm{g} \mathrm{COD/g}$ MLVSS which can be considered as a favorable condition for nitrification and removal of TKN. Andrade et al. (2013) observed nitrification process with the F/M of between 0.55 and $0.67 \mathrm{~g} \mathrm{COD/g} \mathrm{MLVSS.}$ However, total nitrogen (TN) removal is happened under denitrification process. In this study, the high concentration

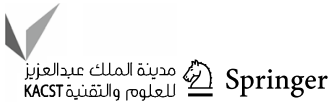


of MLSS and the relative high media viscosity led to reduce efficiency of oxygen transfer and air incomplete distribution in bioreactor. Consequently, anoxic zone is formed into bioreactor which provided favorable conditions for denitrification (Guadie et al. 2013; Puznava et al. 2000). However, the results presented in Table 3 show that the removal efficiency of both parameters is not very high which is maybe due to high influent concentration of nitrogenous compounds in terms of TN and TKN.

Phosphorus removal efficiencies of ${ }^{\mathbf{2}} 55 \%$ were obtained all over the experiments (see Table 3). Conventionally, processes which have been considered appropriate for phosphorus removal must possess sequential aerobic and anaerobic conditions to create a convenient environment for the phosphate accumulating microorganisms' growth (PAOs) (Von Sperling 2005). However, as aforementioned above, the high biomass concentrations applied in this system might lead to formation of microniches of anoxic or anaerobic within the sludge flocs which potentially provide the suitable condition for PAOs (Silva et al. 2012).

Other than phosphorus uptake by PAOs, partial removal of phosphorus is occurred through cell synthesis. The literature has reported similar results in MBR systems with various conditions; for example, Farizoglu et al. (2004) got phosphorus removal efficiencies between 65 and $85 \%$ in an aerobic jet loop membrane bioreactor with influent TP of $420-540 \mathrm{~g} / \mathrm{m}^{3}$. Andrade et al. (2013) reached phosphorus removals of 53 and $83 \%$ for the HRTs of 8 and $6 \mathrm{~h}$, respectively, while the concentrations of influent phosphorus were 27.5 and $20.4 \mathrm{mg} / \mathrm{L}$, respectively. Andrade et al. (2014) in another study with influent phosphorus of $36.3 \mathrm{mg} / \mathrm{L}$ achieved the mean phosphorus removal efficiency of $89 \%$ for HRT of $8 \mathrm{~h}$.

\section{The performance of membrane filtration followed by the bioreactor}

Ultrafiltration can be chosen as an appropriate separation process instead of secondary clarifier in bioreactors. However, widespread application of this technology is restricted by membrane fouling which gives rise to bad consequences such a remarkable increase in operation cost due to fouling mitigation. This fouling may be due to several causes, such as formation of a cake layer on the membrane surface, adsorptive fouling mechanisms and the blockage of membrane pores (Kaya et al. 2010). The membrane used in this study was the optimized membrane $\left(0.1 \mathrm{wt} \%\right.$ of $\left.\mathrm{PES} / \mathrm{NH}_{2}-\mathrm{MWCNTs}\right)$ obtained in an earlier study (Rahimi et al. 2015). The variations of the flux of the membrane as a function of the variables at different operating conditions are represented in Fig. 3. Once the HRT is constant, by increasing the MLSS, an increment in the flux was seen. It could be because of production of more extracellular polymeric substance (EPS) at low concentration

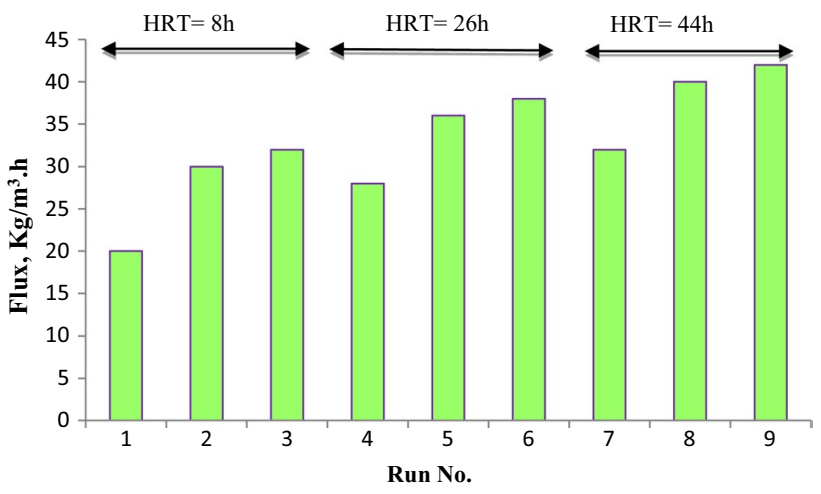

Fig. 3 Flux variations of $0.1 \mathrm{wt} \%$ of $\mathrm{PES} / \mathrm{NH}_{2}-\mathrm{MWCNTs}$ membrane

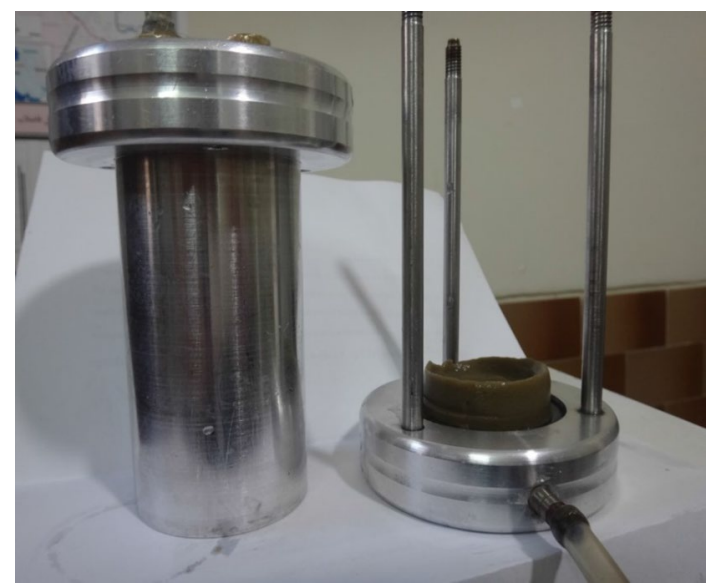

Fig. 4 The formation of cake layer after permeation test with $\mathrm{NH}_{2}$-functionalized MWCNTs polyethersulfone (PES) ultrafiltration membrane filtration for $2 \mathrm{~h}$

of MLSS that accelerates the fouling of membrane via the formation of a cake layer with weak permeability on the membrane surface. The formation of a cake layer after permeation test on PES/ $\mathrm{NH}_{2}$-MWCNTs ultrafiltration membrane surface is displayed in Fig. 4. Similar result was reported by Meng et al. (2007) that flux reduction was consistent with mitigation of biomass concentration attributed to the existence of high EPS and soluble microbial products (SMP) concentrations, as well as high sludge viscosity, due to an increase in the F/M ratio. By contrast, as MLSS concentration was kept constant, and the response was decreased in low HRT, which may be because of an increase in EPS content in the higher F/M ratios (Chae et al. 2006). 


\section{The performance of a high-frequency ultrasound-equipped clarifier followed by the bioreactor}

As stated earlier, to overcome the problems associated with the systems operating in high MLSS, force compaction of the sludge in the clarifier using high-frequency ultrasound is suggested. Therefore, physical characteristics of the sludge at different operating conditions with and without ultrasound are compared in the next sections.

\section{Sludge volume index (SVI)}

Sludge volume index (SVI) was measured to quantify the settling characteristics of the mixed liquor exited from the activated sludge (AS) and ultrasound-equipped activated sludge (US-AS) systems. Figure 5 presents the variations of SVI with respect to HRT and MLSS concentration for the both systems without and with US. As can be seen in the figure, in both systems HRT did not have considerable effect on SVI in the range tested. As MLSS concentration increased, SVI was decreased by producing denser flocs with better settling properties. It can be attributed to the EPS production during cell lysis and subsequent bioflocculation in the condition with high MLSS concentration (Arabi and Nakhla 2009), implying on favored conditions for microbial aggregation at a lower F/M ratio. In contrary, when MLSS decreased from 14,000 to $6000 \mathrm{mg} / \mathrm{L}$, the average particle size may be increased because of a further increase in EPS concentration, leading to an adverse effect on the sludge settling (Chae et al. 2006). The formation of bound EPS is growth-related and is extracted in direct proportion to substrate utilization (Chua et al. 2000). Thus, the increase in the organic loading rate (OLR) or F/M ratio will induce the production of more bound EPS. In addition, the readily biodegradable feed used in this study augmented the generation of more bound EPS in the low MLSS. The increase in the SVI at high OLRs implied on lower sludge compressibility and more viscous bulking (Chae et al. 2006). In this type of bulking, the bacterial cells are swollen by absorbing water to an extent in which their density becomes close to that of water causing poor settleability (Abdollahzadeh Sharghi and Bonakdarpour 2013).

The results exhibited that in the presence of ultrasound waves, SVI was decreased greatly with increase in the MLSS compared to system without ultrasound transducer. As can be seen in the figure, the SVI values were in the range of $60.6-106.8 \mathrm{ml} / \mathrm{g}$ in the presence of ultrasonic irradiation, while they were in higher range of $68.7-138.3 \mathrm{ml} / \mathrm{g}$ in the system without applying sonication. The results of this study were in accordance with Zinadini et al. (2015), where the researchers claimed that the high-frequency ultrasound has a positive effect on the microbial flocculation and compaction of sludge, resulting in a clarifier with required smaller volume. The SVI values of $44.5-59 \mathrm{ml} / \mathrm{g}$ have been reported for reactor containing high-frequency ultrasound that were much less than those of the reactor without ultrasound transducer with values of 61-89 ml/g. According to Rezaee et al. (2014), the highest
Fig. 5 Sludge volume index under different operating conditions

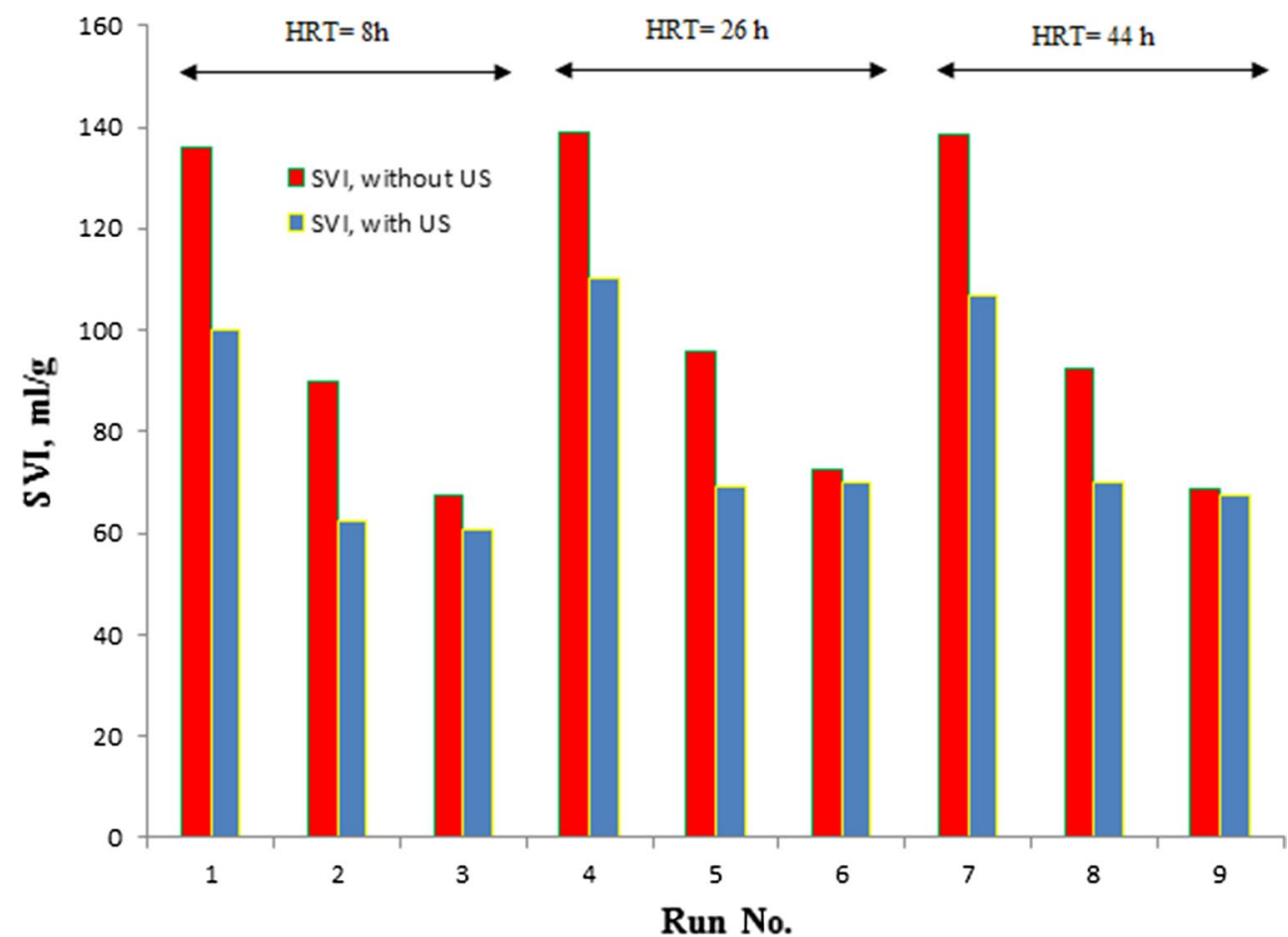

Run No. 
values of the SVI were observed in the feast and famine conditions that led to a damaging effect on sludge settling ability.

Zinadini et al. (2015) found at high content of MLSS, the microstream from ultrasonic waves can create very high mixing and effective mechanical shear force into the reactor. Therefore, these phenomena could lead to formation of compact flocs and subsequently minimize SVI (Zinadini et al. 2015). The influence of ultrasound on the SVI at MLSS concentration over $10,000 \mathrm{mg} / \mathrm{L}$ was not considerable which was because of very high concentration of suspended solids and their adverse interactive effect on settling. Also, the minimum SVI value obtained in research of Rezaee et al. (2014) was $71.69 \mathrm{ml} / \mathrm{g}$ under condition of MLSS of $10,000 \mathrm{mg} / \mathrm{L}$ and HRT of $6 \mathrm{~h}$.

\section{Height of sludge and sludge settling velocity}

As water recovery or clear zone height is a key criterion to design a clarifier, so height of sludge was also monitored rather than SVI. The height of sludge at different operating conditions with and without the ultrasonic irradiation is shown in Fig. 6. As can be realized in the figure, by increasing the MLSS concentration, height of sludge was increased for the both systems. Ultrasonic waves had a less influence on height of sludge in the highest MLSS concentration $(14,000 \mathrm{mg} / \mathrm{L})$. That is attributed to the change of settling process type to hindered settling (Tchobanoglous et al.

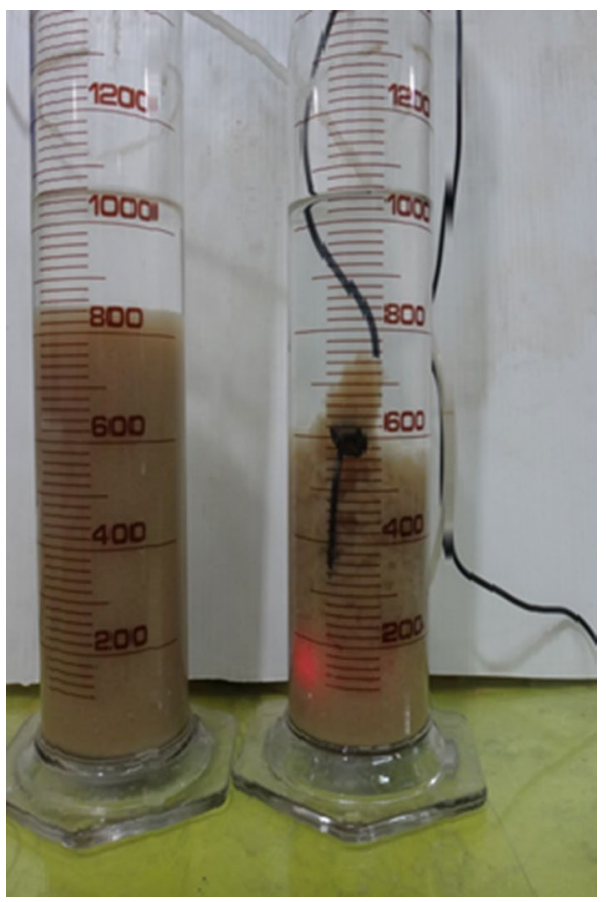

Fig. 7 Effect of 1.7-MHz ultrasound irradiation on sludge volume in comparison with the condition without sonication at MLSS of $6000 \mathrm{mg} / \mathrm{L}$ and $30 \mathrm{~min}$

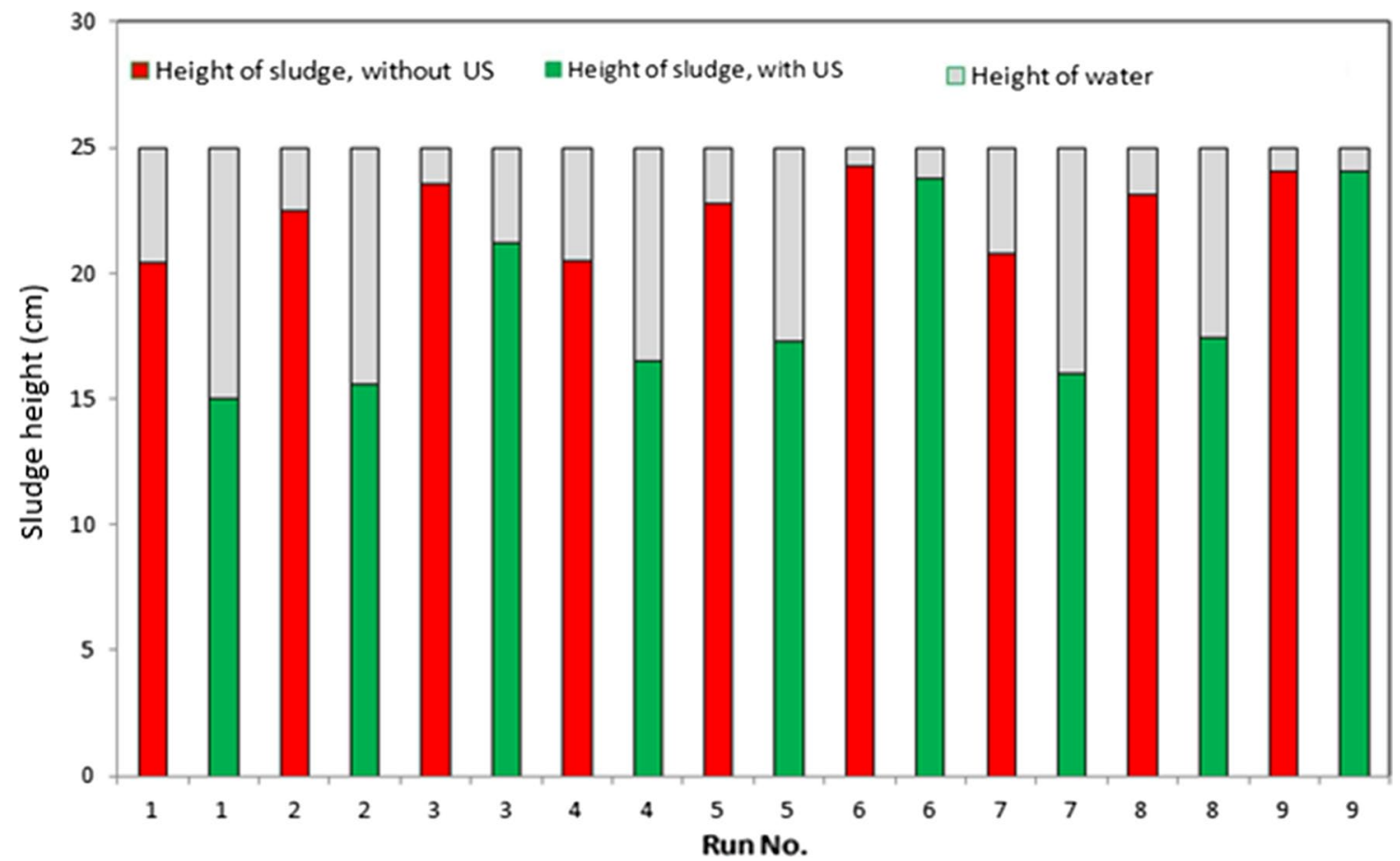

Fig. 6 Height of sludge under different operating conditions 


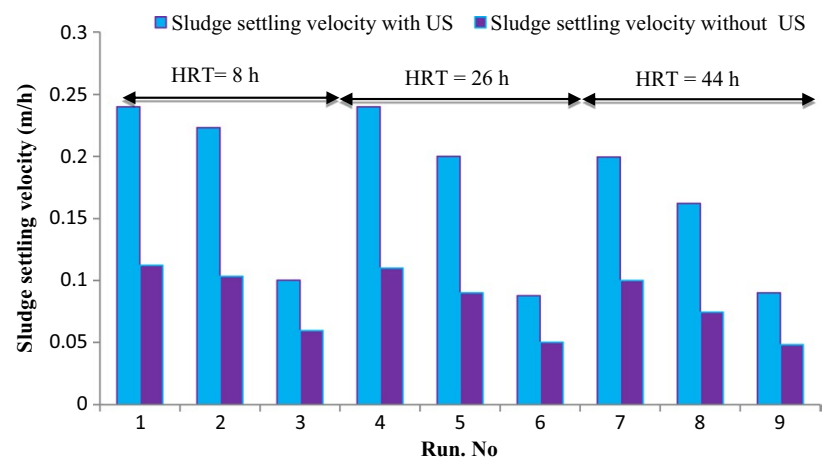

Fig. 8 Sludge settling velocity for the systems with and without US under different operating conditions studied

2003). In this situation, the liquid tends to move upward through the interstices of the contacting particles. As the particles settle, a relatively clear layer of water is formed on top of the particles in the settling region. The rate of settling in such a system is dependent on the biomass concentration and its characteristics. As shown in Fig. 7, an identifiable interface between the upper zone and the hindered settling zone is created. Except the conditions with MLSS of 14,000 mg/L, ultrasound showed remarkable effect on sludge compression. So that at MLSS of $<10,000 \mathrm{mg} / \mathrm{L}$ about $40 \%$ water recovery was obtained in the ultrasoundinduced system that might be related to low sludge concentration and good flocculation (Rezaee et al. 2014). Sludge settling velocity is another critical parameter for clarifier design. High settling velocity implies on less settling tank volume required. Figure 8 illustrates sludge settling velocity at different operating conditions. As presented in the figure, sludge settling velocity was in the ranges of $0.088-0.240$ and $0.051-0.112 \mathrm{~m} / \mathrm{h}$, respectively, for the bioreactor with and without ultrasonication. As a conclusion, operation of the activated sludge system at high biomass concentration (up to $10,000 \mathrm{mg} / \mathrm{L}$ ) will be possible by employing highfrequency ultrasound in the clarifier. Zinadini et al. (2015) reported the sludge settling velocity decreased after increasing the MLSS concentration to more than $5000 \mathrm{mg} / \mathrm{L}$. The reduced sludge settling velocity was affected by high EPS concentration with negative charge, which causes the surface charge of microbes become more negative. Thus, repulsive forces between cells are enhanced, whereas diminishes the settling ability.

\section{The quality comparison of effluent from two approaches studied}

As far as the COD content of the influent feed is the same as soluble COD (SCOD), so effluent turbidity displays biomass washout degree. Turbidity, a measure of the light-transmitting properties of water, is used to indicate the amount of waste discharge and natural water with respect to colloidal and residual suspended matter (Akhbari et al. 2011). In the current work, the system performance was examined by controlling turbidity of the membrane permeate and the bioreactor effluent after ultrasound-induced clarifier. Findings revealed that turbidity was significantly decreased from the influent mean of 174.6 NTU to zero NTU in the membrane permeate and less than 10 NTU for the effluent after clarification. It revealed an excellent performance of the ultrafiltration membrane in relation to the effluent turbidity removal and total suspended solids (TSS) removal as well. However, the ultrasonication could also separate solids from the mixed liquor and provide an effluent with turbidity $<10 \mathrm{NTU}$ which is standard for irrigation as well as discharge into the receiving waters. The values of effluent turbidity obtained by Rezaee et al. (2014) were ranged from 2 to 16 NTU. In the study reported by Zinadini et al. (2015) the ultrasonic waves did not show any effect on effluent turbidity.

\section{Conclusions}

In this work, the performance of an activated sludge system combined with a laboratory-made $\mathrm{PES} / \mathrm{NH}_{2}$-MWCNTs UF membrane with high antifouling property and an ultrasoundequipped activated sludge was comparatively studied in treatment of milk processing wastewater. The effects of two operating parameters viz. MLSS and HRT on the biological performance in terms of sludge characteristics and flux, were investigated. Based on the obtained results, MLSS concentration and HRT had an increasing impact on the flux. However, the membrane and high-frequency ultrasound revealed no influence on removal efficiency of soluble compounds. Furthermore, the use of the ultrasonic transducer had no considerable destructing effect on the biological activity of the biomass and an effluent with high quality was achieved. As a conclusion, this system as a high rate process with smaller footprint can be considered as a promising approach to upgrade the activated sludge process. Nevertheless, it is also pointed out that application of the high-frequency ultrasound in industrial scale needs further comprehensive feasibility studies.

Acknowledgements The authors also wish to thank Razi University and the Ministry of Science and Technology, Iran, for their financial support.

Open Access This article is distributed under the terms of the Creative Commons Attribution 4.0 International License (http://creativeco mmons.org/licenses/by/4.0/), which permits unrestricted use, distribution, and reproduction in any medium, provided you give appropriate credit to the original author(s) and the source, provide a link to the Creative Commons license, and indicate if changes were made. 


\section{References}

Abdollahzadeh Sharghi E, Bonakdarpour B (2013) The study of organic removal efficiency and halophilic bacterial mixed liquor characteristics in a membrane bioreactor treating hypersaline produced water at varying organic loading rates. Biores Technol 149:486-495

Akhbari A, Zinatizadeh AAL, Mohammadi P, Irandoust M, Mansouri Y (2011) Process modeling and analysis of biological nutrients removal in an integrated RBC-AS system using response surface methodology. Chem Eng J 168(1):269-279

American Public Health Association (APHA) (1999) Standard methods for the examination of water and wastewater, 20th edn. APHA, Washington

Andrade LH, Motta GE, Amaral MCS (2013) Treatment of dairy wastewater with a membrane bioreactor. Braz J Chem Eng 30(4):759-770

Andrade LH, Mendes FDS, Espindola JC, Amaral MCS (2014) Nanofiltration as tertiary treatment for the reuse of dairy wastewater treated by membrane bioreactor. Sep Purif Technol 126:21-29

Arabi S, Nakhla G (2009) Characterization of foulants in conventional and simultaneous nitrification and denitrification membrane bioreactors. Sep Purif Technol 69(2):153-160

Bussemaker MJ, Zhang D (2014) A phenomenological investigation into the opposing effects of fluid flow on sonochemical activity at different frequency and power settings. 1. Overhead stirring, Ultrason. Ultrason Sonochem 21(1):436-445

Castillo S, Zapico A, Doubrovine N, Lafforgue C, Fonade C (2007) Study of a compact bioreactor for the in-line treatment of dairy wastewaters: case of effluents produced on breeding farms. Desalination 214(1-3):49-61

Chae S-R, Ahn Y-T, Kang S-T, Shin H-S (2006) Mitigated membrane fouling in a vertical submerged membrane bioreactor (VSMBR). J Membr Sci 280(1-2):572-581

Chan YJ, Chong MF, Law CL, Hassell DG (2009) A review on anaerobic-aerobic treatment of industrial and municipal wastewater. Chem Eng J 155(1-2):1-18

Chua H, Peter HFY, Shirley NS, Kok NT (2000) Effect of food: microorganism ratio in activated sludge foam control. Appl Biochem Biotechnol 84:1127-1135

Cicek N (2003) A review of membrane bioreactors and their potential application in the treatment of agricultural wastewater. Can Biosyst Eng 45:6.37-6.49

Farizoglu B, Keskinler B, Yildiz E, Nuhoglu A (2004) Cheese whey treatment performance of an aerobic jet loop membrane bioreactor. Process Biochem 39(12):2283-2291

Ghasemi M, Wan Daud WR, Alam J, Ilbeygi H, Sedighi M, Ismail AF, Yazdi MH, Aljlil SA (2016a) Treatment of two different water resources in desalination and microbial fuel cell processes by poly sulfone/sulfonated poly ether ether ketone hybrid membrane. Energy 96:303-313

Ghasemi M, Ahmad A, Jafary T, Azad Abul K, Kakooei S, Wan Daud WR, Sedighi M (2016b) Sulfonated poly ether ether ketone with different degree of sulphonation in microbial fuel cell: application study and economical analysis. Int J Hydrogen Energy 41(8):4862-4871

Ghasemi M, Wan Daud WR, Javed Alam, Jafari Yaghoob, Sedighi Mehdi, Aljlil Saad A, Ilbeygi Hamid (2017) Assessment of immobilized cell reactor and microbial fuel cell for simultaneous cheese whey treatment and lactic acid/electricity production. Int J Hydrogen Energy 42(14):9107-9115

Gibson JH, Hon H, Farnood R, Droppo IG, Seto P (2009) Effects of ultrasound on suspended particles in municipal wastewater. Water Res 43(8):2251-2259
Gondrexon N, Renaudin V, Petrier C, Clement M, Boldo P, Gonthier Y, Bernis A (1998) Experimental study of the hydrodynamic behaviour of a high frequency ultrasonic reactor. Ultrason Sonochem $5(1): 1-6$

Guadie A, Xia S, Zhang Z, Guo W, Ngo HH, Hermanowicz SW (2013) Simultaneous removal of phosphorus and nitrogen from sewage using a novel combo system of fluidized bed reactor-membrane bioreactor (FBR-MBR). Biores Technol 149:276-285

Hai FI, Yamamoto K, Fukushi K (2005) Different fouling modes of submerged hollow- fiber and flat-sheet membranes induced by high strength wastewater with concurrent biofouling. Desalination 180(1-3):89-97

Hocaoglu SM, Insel G, Cokgor EU, Orhon D (2011) Effect of sludge age on simultaneous nitrification and denitrification in membrane bioreactor. Bioresour Technol 102(12):6665-6672

Jianlong W, Hanchang S, Yi Q (2000) Wastewater treatment in a hybrid biological reactor (HBR): effect of organic loading rates. Process Biochem 36(4):297-303

Kanthale P, Ashokkumar M, Grieser F (2008) Sonoluminescence, sonochemistry $\left(\mathrm{H}_{2} \mathrm{O}_{2}\right.$ yield $)$ and bubble dynamics: frequency and power effects. Ultrason Sonochem 15(2):143-150

Kaya Y, Gönder ZB, Vergili I, Barlas H (2010) The effect of transmembrane pressure and $\mathrm{pH}$ on treatment of paper machine process waters by using a two-step nanofiltration process: flux decline analysis. Desalination 250(1):150-157

Liang Z, Das A, Beerman D, Hu Z (2010) Biomass characteristics of two types of submerged membrane bioreactors for nitrogen removal from wastewater. Water Res 44(11):3313-3320

Luostarinen S, Luste S, Valentín L, Rintala J (2006) Nitrogen removal from on-site treated anaerobic effluents using intermittently aerated moving bed biofilm reactors at low temperatures. Water Res 40(8):1607-1615

Mason TJ (2007) Developments in ultrasound-non-medical. Prog Biophys Mol Biol 93(1-3):166-175

Mason TJ, Lorimer JP (2002) Applied sonochemistry: the uses of power ultrasound in chemistry and processing. Wiley VCH Weinheim, Germany

Matošić M, Prstec I, Jakopović HK, Mijatović I (2009) Treatment of beverage production wastewater by membrane bioreactor. Desalination 246(1-3):285-293

Meng F, Shi B, Yang F, Zhang H (2007) Effect of hydraulic retention time on membrane fouling and biomass characteristics in submerged membrane bioreactors. Bioprocess Biosyst Eng 30(5):359-367

Pell M, Wörman A (2011) Biological wastewater treatment systems. Compr Biotechnol 6:275-290

Puznava N, Payraudeau M, Thornberg D (2000) Simultaneous nitrification and denitrification in biofilters with real-time aeration control. Water Sci Technol 43(1):269-276

Rahimi Z, Zinatizadeh AA, Zinadini S (2015) Preparation high antibiofouling amino functionalized MWCNTs/PES nanocomposite ultrafiltration membrane for application in membrane bioreactor. J Ind Eng Chem 29:366-374

Rahimi Z, Zinatizadeh AA, Zinadini S (2016) Milk processing wastewater treatment in a bioreactor followed by an antifouling $\mathrm{O}$-carboxymethyl chitosan modified $\mathrm{Fe}_{3} \mathrm{O}_{4} / \mathrm{PVDF}$ ultrafiltration membrane. J Ind Eng Chem 38:103-112

Rezaee S, Zinatizadeh AAL, Asadi A (2014) High rate CNP removal from a milk processing wastewater in a single ultrasound augmented up-flow anaerobic/aerobic/anoxic bioreactor. Ultrason Sonochem 23:289-301

Rhoida Eco Services Group (1998) A new development in membrane bioreactors: increasing the capacity of existing biological treatment plants. Filtr Sep 10:792-795

Silva AF, Carvalho G, Oehmen A, Lousada-Ferreira M, Nieuwenhuijzen A, Reis MAM, Crespo MTB (2012) Microbial population 
analysis of nutrient removal-related organisms in membrane bioreactors. Environmental Biotechnology 93(5):2171-2180

Sipma J, Osuna B, Collado N, Monclús H, Ferrero G, Comas J, Rodriguez-Roda I (2010) Comparison of removal of pharmaceuticals in MBR and activated sludge systems. Desalination 250(2):653-659

Sombatsompop KM (2007). Membrane fouling studies in suspended and attached growth membrane bioreactor systems. Asian Institute of Technology School of Environment, Resource s and Development Environmental Engineering and Management, Thailand

Tchobanoglous G, Burton F, Stensel HD (2003) Wastewater engineering: treatment and reuse. McGraw-Hill, New York

Visvanathan C, Aim RB, Parameshwaran K (2000) Membrane separation bioreactors for wastewater treatment. Crit Rev Environ Sci Technol 30(1):1-48
Von Sperling M (2005) Princípios do tratamento biológico de águas residuárias: Lodos ativados (Principles of biological wastewater treatment: activated sludge). Segrac, Belo Horizonte

Zheng Y-M, Yu H-Q, Sheng G-P (2005) Physical and chemical characteristics of granular activated sludge from a sequencing batch airlift reactor. Process Biochem 40(2):645-650

Zinadini S, Rahimi M, Zinatizadeh AA, Shaykhi Mehrabadi Z (2015) High frequency ultrasound-induced sequence batch reactor as a practical solution for high rate wastewater treatment. J Environ Chem Eng 263(1):101-112

Publisher's Note Springer Nature remains neutral with regard to jurisdictional claims in published maps and institutional affiliations.

\section{Affiliations}

\section{Z. Rahimi ${ }^{1} \cdot$ A. A. Zinatizadeh ${ }^{1}$}

1 Environmental Research Center (ERC), Department of Applied Chemistry, Faculty of Chemistry, Razi University, Kermanshah, Iran 